\title{
Plant species and habitat structure in a sand dune field in the Brazilian Caatinga: a homogeneous habitat harbouring an endemic biota
}

\author{
PEDRO LUÍS B. DA ROCHA ${ }^{1,4}$, LUCIANO P. DE QUEIROZ² and JOSÉ RUBENS PIRANI ${ }^{3}$
}

(received: August 22, 2003; accepted: August 12, 2004)

\begin{abstract}
Plant species and habitat structure in a sand dune field in the Brazilian Caatinga: a homogeneous habitat harbouring an endemic biota). One dune habitat in the semi-arid Caatinga Biome, rich in endemisms, is described based on plant species composition, woody plant density, mean height and phenology and a multivariate analysis of the micro-habitats generated by variables associated to plants and topography. The local flora is composed mainly by typically sand-dweller species of Caatinga, suggesting the existence of a phytogeographic unity related to the sandy areas in the Caatinga biome, which seems to be corroborated by faunal distribution. Moreover, some species are probably endemic from the dunes, a pattern also found in vertebrates. The plant distribution is patchy, there is no conspicuous herbaceous layer and almost $50 \%$ of the ground represents exposed sand. Phenology is not synchronized among species, occurring leaves budding and shedding, flowers development and anthesis, fruits production and dispersion both in rainy and dry seasons. Leaf shedding is low compared to the level usually observed in Caatinga areas and about 50\% of the woody individuals were producing leaves in both seasons. Spectrum of dispersal syndromes shows an unexpected higher proportion of zoochorous species among the phanerophytes, accounting for $31.3 \%$ of the species, $78.7 \%$ of the total frequency and $78.6 \%$ of the total density. The habitat of the dunes is very simple and homogeneous in structure and most of environmental variance in the area is explained by one gradient of woody plants density and another of increase of Bromelia antiacantha Bertol. (Bromeliaceae) and Tacinga inamoena (K. Schum.) N.P. Taylor \& Stuppy (Cactaceae) toward valleys, which seem to determine two kinds of protected micro-habitats for the small cursorial fauna.
\end{abstract}

Key words - density, endemic species, phenology, phytogeography, semiarid

RESUMO - (Espécies vegetais e estrutura do hábitat em um campo de dunas arenosas na Caatinga brasileira: um hábitat homogêneo portando uma biota endêmica). Um ambiente de dunas no bioma Caatinga, rico em endemismos, é descrito a partir da composição florística, da densidade, altura média e fenologia das espécies lenhosas e de uma análise multivariada dos microhábitats criados por variáveis associadas às plantas e à topografia. A flora local é composta principalmente por espécies típicas de áreas arenosas da caatinga, sugerindo a existência de uma unidade fitogeográfica na caatinga relacionada a áreas arenosas, o que parece ser corroborado por dados faunísticos. Além disso, algumas espécies são provavelmente endêmicas das dunas, padrão também observado nos vertebrados. A vegetação possui distribuição agregada, não há estrato herbáceo conspícuo e quase 50\% do solo representa areia nua. A fenologia das espécies não é sincronizada, ocorrendo brotamento e queda de folhas, desenvolvimento e antese de flores e produção e dispersão de frutos nas estações seca e chuvosa. A caducifolia é particularmente baixa em comparação com outras áreas de caatinga e cerca de 50\% dos indivíduos lenhosos produz folhas nas duas estações. O espectro de síndromes de dispersão mostra uma proporção de espécies zoocóricas inesperadamente alta entre as fanerófitas, representando $31,3 \%$ das espécies, $78,7 \%$ da frequêencia total e 78,6\% da densidade total. O hábitat possui estrutura bastante simples e homogênea: a maioria da variância na área é explicada por um gradiente de densidade de lenhosas e outro de aumento de Bromelia antiacantha Bertol. (Bromeliaceae) e Tacinga inamoena (K. Schum.) N.P. Taylor \& Stuppy (Cactaceae) em direção aos vales, determinando dois tipos de micro-hábitats protegidos para a fauna cursora de pequeno porte.

Palavras-chave - densidade, espécies endêmicas, fenologia, fitogeografia, semi-árido

\section{Introduction}

The Caatinga Morphoclimatic Dominium extends over an area of about $700,000 \mathrm{~km}^{2}$ of Northeast Brazil

1. Universidade Federal da Bahia, Instituto de Biologia - Campus de Ondina. 40170-290 Salvador, BA, Brazil.

2. Universidade Estadual de Feira de Santana, Departamento de Ciências Biológicas - km 03 BR 116, Campus. 44031-460 Feira de Santana, BA, Brazil.

3. Universidade de São Paulo, Instituto de Biociências, Departamento de Botânica, Caixa Postal 11461, 05422-970 São Paulo, SP, Brazil.

4. Corresponding author: peurocha@ufba.br
(Ab'Saber 1974) and represents one of the most inhospitable Brazilian landscapes due to a peculiar conjunction of physical factors. The mean annual temperature of about $28^{\circ} \mathrm{C}$ makes it one of the hottest semiarid areas of the world. Its rains are scanty and unevenly distributed in time and space, its water courses are seasonally intermittent and its soils have scarce or even null water stocks (Ab'Saber 1974, Andrade-Lima 1981, Sampaio 1995).

The number of endemic plant species in the biome Caatinga is high (Rizzini 1979, Prado 2000) reaching almost $30 \%$ of the total flora (Giulietti et al. 2002). 
However, the vegetation of this biome is highly variable in structure and floristic composition in a local scale and different vegetations types had been proposed to highlight this heterogeneity (see summaries in AndradeLima 1981 and Rodal \& Sampaio 2002). These include different caatinga vegetations based on tree profile, probably related to different soil and water conditions (Andrade-Lima 1981), and a vegetation with a particular floristic composition occurring on sandy soils and higher altitudes called carrasco (Araújo et al. 1998). More recentely, Pennington et al. (2000) and Prado (2000) proposed the Neotropical seasonally dry forests as a new phytogeographical province and considered the Caatinga as one of its nucleus based on distribution patterns of genera present in different dry areas of the Neotropics. Moreover, the flora of the Caatinga shows several adaptations to deal with water scarcity. It is characterized by the presence of succulent plants (mainly Cactaceae and Euphorbiaceae), thorny bushes and terrestrial bromeliads. Additionally, most plants, especially trees and shrubs, have small, thin leaves and their abscission during droughts is the most significant response to the water stress (Holbrook et al. 1995). The activity of their stomata is fast, the stomata are kept closed most of time, and transpiration is restricted even during the wet season (Ferri 1955).

The terrestrial vertebrate fauna of the biome Caatinga, on the other hand, has been supposed to show very little adaptations to this stressful habitat: some works have proposed that small mammal populations aggregate on the rock outcroppings where microhabitat conditions are more mesic (Streilein 1982c) as there are no physiological adaptations in these animals to restrict water lose and to deal with long periods of droughts (Mares et al. 1985, Streilein 1982a, b). The number of endemic species of reptiles, birds and mammals has also been considered very low (Sick 1965 apud Mares et al. 1985, Vanzolini et al. 1980, Willig \& Mares 1989). The mastofauna of Caatinga, for example, is supposed to represent an impoverished subset of those from Atlantic forest and Cerrados (Mares et al. 1985), including only 80 species (Willig \& Mares 1989). More recent studies, however, have detected at least 143 species in the biome (Oliveira et al. 2003). Some authors suggested that some species may have physiological adaptations to the semiarid conditions (Barros et al. 1998, Ribeiro et al. 2004) and that the causal factors underlying the pattern of small mammal abundances in the Caatinga probably includes variables other than structural complexity of the substratum and humidity and shelter availability, as amount of herbs and litter, plant species richness, and amount of loose gravel (Rocha, unpublished data).

Moreover, recent zoological studies in the State of Bahia (Brazil) have lead to the discovering of a region that, in spite of its small extent relative to the Caatinga biome (c. $7.000 \mathrm{~km}^{2}$, Oliveira et al. 1999), holds several endemic genera and species (Sauria, Serpentes, Amphisbaenia, Aves, Rodentia), many of which show morphological and behavioral adaptations to psammophily (Lencioni-Neto 1994, Rocha 1995, Rodrigues 1996). The area, referred to as "The Little Sahara along the São Francisco River" (Williams 1925 apud Oliveira et al. 1999) is a palaeodesert consisting of an extensive and inactive dune field that lies on the banks of the middle São Francisco River, between Barra and Pilão Arcado (Rodrigues 1996).

During the executions of two research projects focusing the ecology of squamates and rodents from the dunes (Rocha 1991, 1998), data were collected on the local flora in order to appreciate the resources available to the fauna. Due to the intrinsic biological importance of the dunes and to the general lack of quantitative information on the Caatinga vegetation, floristic and phytosociological data were collected in order to describe qualitatively and quantitatively the local plant community. The first objective of the present article is to present one description of this important ecosystem based on: (1) the plant species composition, (2) the density estimates and height distributions of the woody species, (3) data of the phenology and dispersion syndromes of the species and (4) a multivariate description of the microhabitat in the dunes based on the variables used in (2) and on topography, on the proportion of plants of different habits, on the level of shade, and on the amount of litter. The second objective is to discuss evidences suggesting that plant species in the dunes represent one phytogeographic unity related to other sandy areas and different from the Neotropical seasonally dry forests. The third objective is to discuss the ways the habitat structure in the dunes may influence the local fauna.

\section{Methods}

The study site - The dunes are located in one strip of arid and semiarid climates extending southwest from Raso da Catarina, along the valley of middle São Francisco River, where mean annual temperatures are the highest in the state of Bahia, exceeding $26.2^{\circ} \mathrm{C}$ (Bahia-Seplantec 1978). Records from meteorological station closest to Ibiraba, in Barra (ca. $50 \mathrm{~km} \mathrm{SW}$ of Ibiraba), indicate annual mean rainfall of $692 \mathrm{~mm}$ (ranging from 400 to $800 \mathrm{~mm}$ ), dry season of 7 to 8 
months and rain season from October to March (Nimer 1979). The fieldwork was performed in sand dunes of Ibiraba village, Barra, in Bahia state (10 $40^{\circ}$ ' $\mathrm{S}$ and $\left.42^{\circ} 50^{\prime} \mathrm{W}\right)$. The study area is about $500 \mathrm{~m}$ away from the nearest village, that occupies mainly lowlands in the flooding plain of São Francisco River, near Icatu River. The dunes are apparently undisturbed by recent human action except for some extraction of wood for fire making. Indeed, the local human demographic density (less than 5 inhabitants. $\mathrm{km}^{-2}$ ) is one of the lowest for the State (Bahia-Seplantec 1978).

The studied area represents the third of the five geomorphologic dominia of the sandy seas in the middle São Francisco River, as classified by Barreto (1996). In this dominium of dunes with sharp morphology, dune summits stand about $40 \mathrm{~m}$ higher than the river level, and up to $20 \mathrm{~m}$ higher than the dune valleys. Vegetation physionomy on the dunes differs from that on neighbor alluvial plain for in the first the trees and bushes are shorter and patchier in distribution and there is not a conspicuous herbaceous covering even in the raining season. Therefore, most of sandy soil rests exposed, except for the presence of patches covered by the terrestrial bromeliad Bromelia antiacantha Bertol., by the small cacti Tacinga inamoena (K. Schum.) N.P. Taylor \& Stuppy and by litter.

Field procedures and data analysis - Six expeditions were accomplished. The first two took place in AugustOctober/1988 and January-February/1989, and the last four in February-March/1996, September/1996, December/1996 and February-March/1997. The species list was obtained by collecting in a 10 ha sand dune area during 1988, 1989 and 1997 expeditions. Vernacular names of plant species were obtained by interviews with the local population. Vouchers of the botanical material obtained are housed in the herbaria HUEFS and SPF (acronyms according to Holmgreen et al. 1990).

Quantitative analyses were based on data obtained from sampling grids and included the following three items:

(1) Density estimate and distribution of height frequencies of woody species - (data collected in 1989) The point-quarter method described in Krebs (1999) was applied for 210 sampling points in two grids ( 11 columns $\times 10$ lines) plotted $50 \mathrm{~m}$ apart. Distance between successive rows and between successive columns was $20 \mathrm{~m}$. Woody individuals taller than $1.5 \mathrm{~m}$ were included in the sampling and their height and species recorded.

(2) Evaluation of phenologic state of woody species - In 1989 the phenologic state of the trees and shrubs, whose fruits and seeds were supposed to be consumed by the endemic rodent Trinomys yonenagae Rocha (Eugenia sp., Copaifera coriacea Mart., Simaba ferruginea A. St-Hil., Byrsonima gardnerana A. Juss., Jatropha mutabilis (Pohl) Baill., and Bombacopsis retusa (Mart. \& Zucc.) A. Robyns), were evaluated. A total of 110 points per grid was used to sample the nearest individual (distance $\leq 10 \mathrm{~m}$ ) taller than $1.0 \mathrm{~m}$ of each species in each quadrant. For each individual it was recorded the presence or absence of leaves, flowers and fruits. In each one of the four field campaigns from 1996 to 1997 the phenology analysis was broadened to include all the woody species (individuals higher than $1.0 \mathrm{~m}$ ), sampled by the quarter-point method based on four parallel transects with one sampling point every $25 \mathrm{~m}$ (10 points per transect). Each sampled specimen was identified and its phenologic state (presence and absence) related to leaves (budding and shedding), flowers (development and anthesis), and fruits (development and dispersion) was recorded.

Spectrum of the dispersal syndromes was determined by analyses of the morphological characters of the dispersal units and comparing them to the classes of dispersal syndromes proposed by Pijl (1972). For the present study, barochory was included in the class of autochory.

(3) Multivariate description of the habitat structure (performed for the 1989 data) - The microgeographic position of the sampling points in the dunes was recorded as a nominal variable with four levels: summit (SUM: horizontal area leading to at least two descending slopes), valley (VAL: horizontal area leading to at least two ascending slopes), slope (SLO), and plateau (PLA: horizontal area leading to at least one descending and one ascending slope). A $4 \mathrm{~m}$ diameter circle centered in each point was used to evaluate the relative contribution of horizontal projection of trees (TRE: woody individuals with a single main stem, undivided near the soil), of shrubs (SHR: woody individuals with multiple stems rising from the soil + sub-shrubs), of herbaceous plants (HER: almost exclusively Bromelia antiacantha Bertol. and Tacinga inamoena (K. Schum.) N.P. Taylor \& Stuppy), and of exposed sand (SAN). In order to estimate these values, an integer value (0 to 10 ) was attributed to each variable in a way that the four values per circle summed 10 . The proportion of exposed soil (without plants) in each circle was evaluated for amount of litter (LIT) by attributing a value from 1 to 3 (little litter, equal parts of litter and uncovered sand, much litter). Each circle was also evaluated for the amount of shade (SHA), depending on the amount of branches in trees and shrubs, by attributing a value from 1 to 3 (little shade, median shade, much shade). Finally, it was computed the main height of (HEI) and mean distance to (DIS) the four closest woody individuals sampled per point by the point-quarter method. The variables TRE, SHR, HER, LIT, SHA, HEI, and DIS plus three binary (dummy) variables derived from the microgeographic region (SUM, VAL, and SLO) were reduced by a Factor Analysis based on the PCA model (Statistica for Windows, release 5.1, 1997) in order to detect orthogonal sets of highly correlated variables. The variable SAN and fourth level of the nominal variable (PLA) were ignored in order to avoid the colinearity effect. The analysis was performed for the total data (two grids) extracting the factors associated to latent roots (eigenvalues) greater than 1.000 and applying the VARIMAX orthogonal rotation, which simplifies the structure related to the components (Kleibaun et al. 1988). When used for the sake of description of data, 
and not for hypothesis testing, factor analyses can hold wide departures from the ideal conditions as data normality (Gauch 1982), as in the data presented here.

Additionally, three profiles of the local plant community were drawn in order to graphically represent the structure of plant covering in a strip 2 meter wide in the summit, slope and valley.

\section{Results}

The floristic survey has detected 86 species in 37 families (table 1). The richest families were Leguminosae (24 species), Euphorbiaceae (9), and Cactaceae (5). Bignoniaceae, Convolvulaceae, Sterculiaceae, and Turneraceae were represented by three species each, while Cyperaceae, Loranthaceae, Malvaceae, Molluginaceae, Rubiaceae, and Sapindaceae by two species each. The remaining 24 families were represented by only one species each. Some of the species either are still undescribed (Eugenia sp., probably an undescribed species; M.L. Kawasaki, personal communication) or were described during and after the 1980's (e.g., Mimosa xiquexiquensis, Barneby 1991, and Pterocarpus monophyllus, Klitgaard et al. 2000). Until now, Dioclea marginata was known only by the type, collected during the XIX century (Maxwell 1969). More than half of all the sampled species are trees or shrubs $(50.6 \%)$, and the herbaceous and subshrub strata contribute only with $29.4 \%$ of the sampled species. Succulents represent $5.9 \%$ the species in the

Table 1. List of plant species from the dunes of Ibiraba, Bahia, Brazil, habits, dispersal syndromes, and their vernacular names collected with the local population. Code refers to the plant numbers represented in the profiles (figure 5). Vouchers: $\mathrm{Q}=$ collection by L.P. Queiroz; R = collection by P.L.B. Rocha. Dispersal syndromes: ANEM = anemochory; AUTO = autochory + barochory; $\mathrm{EPIZO}=$ epizoochory; ZOOC = zoochory (fleshy fruits or with fleshy seed arils).

\begin{tabular}{|c|c|c|c|c|c|}
\hline Family/Species & Code & Vernacular names & Habit & $\begin{array}{l}\text { Dispersal } \\
\text { syndrome }\end{array}$ & Voucher \\
\hline \multicolumn{6}{|l|}{ ACANTHACEAE } \\
\hline $\begin{array}{l}\text { Harpochilus neesianus Mart. ex Nees } \\
\text { AMARANTHACEAE }\end{array}$ & 9 & brinco & Shrub & AUTO & Q 4793, 4887; R 11, 48 \\
\hline $\begin{array}{l}\text { Alternanthera amabilis Hort. ex Lem. } \\
\text { ANNONACEAE }\end{array}$ & - & - & Herb & AUTO & Q4828 \\
\hline $\begin{array}{l}\text { Annona spinescens Mart. } \\
\text { APOCYNACEAE }\end{array}$ & - & araticum & Tree & ZOOC & Q4833,6418 \\
\hline $\begin{array}{l}\text { Allamanda puberula A.DC. } \\
\text { BIGNONIACEAE }\end{array}$ & - & canela-de-ema & Shrub & ANEM & Q 4821; R 33 \\
\hline Godmania dardanoi (J.C. Gomes) A.H. Gentry & $y-$ & - & Tree & ANEM & Q4800 \\
\hline Proterantha glandulosa A.H. Gentry ined. & - & - & Liana & ANEM & Q6441 \\
\hline $\begin{array}{l}\text { Tabebuia heptaphylla (Vell.) Toledo } \\
\text { BOMBACACEAE }\end{array}$ & - & ipê-roxo & Tree & ANEM & Q 4787; R 12 \\
\hline $\begin{array}{l}\text { Bombacopsis retusa (Mart. \& Zucc.) A. Robyns } \\
\text { BORAGINACEAE }\end{array}$ & is - & castanha & Tree & AUTO & Q 4812, 6448; R 7 \\
\hline $\begin{array}{l}\text { Cordia globosa (Jacq.) Humb., Bonpl. \& Kunth } \\
\text { BROMELIACEAE }\end{array}$ & th - & - & Shrub & AUTO & Q4801, 4877 \\
\hline $\begin{array}{l}\text { Bromelia antiacantha Bertol. } \\
\text { BURSERACEAE }\end{array}$ & 13 & macambira & Herb & ZOOC & Q 4891, 6446; R 9 \\
\hline $\begin{array}{l}\text { Commiphora leptophloeos (Mart.) J.B. Gillett } \\
\text { CACTACEAE }\end{array}$ & - & imburana & Tree & ZOOC & Q 4881, R 41 \\
\hline Arrojadoa penicillata Britton \& Rose & - & rabo-de-cachorro & Succulent & ZOOC & $\mathrm{R} 13$ \\
\hline Cereus albicaulis (Britton \& Rose) Luetzelb. & - & rabo-de-raposa & Succulent & ZOOC & $\mathrm{R} 47$ \\
\hline $\begin{array}{l}\text { Pilosocereus gounellei (F.A.C. Weber) Byles \& } \\
\text { Rowley subsp. gounellei }\end{array}$ & \& - & xique-xique & Succulent & ZOOC & Q 4873; R 22 \\
\hline $\begin{array}{l}\text { Pilosocereus tuberculatus (Werderm.) } \\
\text { Byles \& Rowley }\end{array}$ & 10 & mandacaru & Succulent & ZOOC & Q. 4813; R 23 \\
\hline $\begin{array}{l}\text { Tacinga inamoena (K. Schum.) N.P. Taylor } \\
\text { \& Stuppy }\end{array}$ & 14 & quipá & Succulent & ZOOC & Q 4826; R 4 \\
\hline
\end{tabular}




\begin{tabular}{|c|c|c|c|c|c|}
\hline Family/Species & Code & Vernacular names & Habit & $\begin{array}{l}\text { Dispersal } \\
\text { syndrome }\end{array}$ & Voucher \\
\hline \multicolumn{6}{|l|}{ CELASTRACEAE } \\
\hline Maytenus rigida Mart. & 4 & colher, pau-de-colher & r Tree & ZOOC & Q 4782,6435; R 11 \\
\hline \multicolumn{6}{|l|}{ COMPOSITAE } \\
\hline Vernonia lilacina Mart. ex DC. & - & - & Sub-shrub & ANEM & Q4816 \\
\hline \multicolumn{6}{|l|}{ CONVOLVULACEAE } \\
\hline Evolvulus anagalloides Meisn. & - & rama-de-noiva & Sub-shrub & AUTO & Q 4827; R 28, 53 \\
\hline Ipomoea asarifolia (Desr.) Roem. \& Schult. & - & - & Herb & AUTO & Q4886 \\
\hline Ipomoea setifera Poir. & - & - & Vine & AUTO & Q4888 \\
\hline \multicolumn{6}{|l|}{ CYPERACEAE } \\
\hline Cyperus cf. retrorsus Chapm. & - & - & Herb & EPIZO & Q4785;R 16 \\
\hline Fimbristylis sp. & - & - & Herb & ? & R26 \\
\hline \multicolumn{6}{|l|}{ EUPHORBIACEAE } \\
\hline Chamaesyce alsinifolia Boiss. & - & quebra-pedra & Herb & AUTO & Q 4796; R 34 \\
\hline Cnidoscolus quercifolius Pohl ex Baill. & - & favela & Tree & AUTO & Q6449 \\
\hline Cnidoscolus urens (L.) Arthur & - & cansansão & Shrub & AUTO & Q4874 \\
\hline Croton heliotroiifolius Kunth & - & velame-da-caatinga & Shrub & AUTO & Q4765,4824; R 36 \\
\hline Croton sonderianus Müll.Arg. & 5 & marmeleiro & Shrub & AUTO & Q 4829; R 51 \\
\hline Dalechampia scandens L. & - & urtiga & Vine & AUTO & Q4768, 4862 \\
\hline Jathropha mutabilis (Pohl) Baill. & - & pinhão & Shrub & AUTO & Q4788, 6434; R 39 \\
\hline Manihot caerulescens Pohl & - & maniçoba & Shrub & AUTO & R37 \\
\hline Manihot heptaphylla Ule & - & - & Shrub & AUTO & Q 4772,4865 \\
\hline \multicolumn{6}{|l|}{ LEGUMINOSAE } \\
\hline \multicolumn{6}{|l|}{ Caesalpinioideae } \\
\hline Bauhinia pentandra (Bong.) D.Dietr. & - & - & Shrub & AUTO & Q4892 \\
\hline $\begin{array}{l}\text { Chamaecrista belemii (H.S.Irwin \& Barneby) } \\
\text { H.S.Irwin \& Barneby var. belemii }\end{array}$ & 6 & são-joão-da-caatinga & a Shrub & AUTO & Q4818;R 18 \\
\hline Chamaecrista desvauxii (Collad.) Killip & - & vassourinha & Herb & AUTO & Q4783;R 15 \\
\hline Chamaecrista flexиosa (L.) Greene var. flexиоsa & $a-$ & jurema & Sub-shrub & AUTO & R 29 \\
\hline Copaifera coriacea Mart. & 2 & sapucaia & Tree & $\mathrm{ZOOC}$ & Q 4789, 6457; R 5 \\
\hline Hymenaea eriogyne Benth. & - & jatobá & Tree & AUTO & Q 4804,4834; R 50 \\
\hline Peltogyne pauciflora Benth. & - & resineiro & Tree & $\mathrm{ZOOC}$ & Q4819,4823;R21A, 24 \\
\hline Senna gardneri (Benth.) H.S.Irwin \& Barneby & - & são-joão-da-caatinga & a Shrub & AUTO & Q 4803, 6432; R 18 \\
\hline $\begin{array}{l}\text { Senna macranthera var. pudibunda (Benth.) } \\
\text { H.S.Irwin \& Barneby }\end{array}$ & - & pé-de-cabra & Shrub & AUTO & Q4867 \\
\hline \multicolumn{6}{|l|}{ Mimosoideae } \\
\hline Acacia paniculata Willd. & - & jurema & Tree & AUTO & R 46 \\
\hline Calliandra macrocalyx Harms & - & $\begin{array}{l}\text { orelha-de-onça, } \\
\text { sucupira }\end{array}$ & Tree & AUTO & Q 4879; R 40 \\
\hline Mimosa adenophylla Taub. & - & jurema-lisa & Sub-shrub & ANEM & Q 4798; R 45 \\
\hline Mimosa invisa Mart. ex Colla & - & sensitiva & Shrub & AUTO & Q4882 \\
\hline Mimosa xiquexiquensis Barneby & 11 & melosa & Sub-shrub & EPIZO & Q4784; R 2 \\
\hline Piptadenia moniliformis Benth. & - & $\begin{array}{l}\text { rama-de-bezerro, } \\
\text { folha-miúda }\end{array}$ & Tree & AUTO & Q4878 \\
\hline \multicolumn{6}{|l|}{ Papilionoideae } \\
\hline Aeschynomene martii Benth. & - & - & Shrub & ANEM & Q 4892A; R 55 \\
\hline Bocoa mollis (Benth.) Cowan & 8 & brinco & Shrub & ZOOC & Q 4811,6439; R 30 \\
\hline Centrosema brasilianum (L.) Benth. & - & feijão-bravo & Vine & AUTO & Q4871 \\
\hline Chaetocalyx scandens var. pubescens (DC.) Rudd. & . - & - & Vine & EPIZO & Q4869 \\
\hline Cratylia mollis Mart. ex Benth. & - & camaratuba & Shrub & AUTO & Q4872 \\
\hline Dioclea marginata Benth. & - & mucunã & Liana & AUTO & Q 4790, 6440; R 20 \\
\hline Galactia remansoana Harms & - & - & Vine & AUTO & Q4795 \\
\hline
\end{tabular}


continuation

Family/Species

Code Vernacular names

Habit

Dispersal

syndrome

Papilionoideae (cont.)

Pterocarpus monophyllus Klitg.,

L.P.Queiroz \& G.P.Lewis

Zornia sericea Moric.

LORANTHACEAE

Psittacanthus bicalyculatus Mart.

Strutanthus syringifolius Mart.

MALPIGHIACEAE

Byrsonima gardnerana A.Juss.

MALVACEAE

Pavonia varians Moric.

Sida galheirensis Ulbr.

MELASTOMATACEAE

Mouriri pusa Gardn.

MOLLUGINACEAE

Glischrothamnus ulei Pilg.

Mollugo verticillata $\mathrm{L}$.

MYRTACEAE

Eugenia sp.

OCHNACEAE

Ouratea glaucescens Engl.

\section{OLACACEAE}

Ximenia americana $\mathrm{L}$.

POLYGALACEAE

Polygala mollis Kunth

POLYGONACEAE

Ruprechtia ramiflora (Jacq.) C.A.Mey.

RHAMNACEAE

Ziziphus joazeiro Mart.

RUBIACEAE

Alibertia sp.

Borreria verticillata (L.) G.F.W.Mey.

SAPINDACEAE

Cardiospermum corindum $\mathrm{L}$.

Serjania comata Radlk.

SAPOTACEAE

Sideroxylon obtusifolium (Roem. \& Schult.) T.D.Penn.

SCROPHULARIACEAE

Angelonia blanchetii Benth.

SIMAROUBACEAE

Simaba ferruginea A.St.-Hil.

STERCULIACEAE

Melochia tomentosa L.

Waltheria indica L.

Waltheria brachypetala Turcz.

\begin{tabular}{|c|c|c|c|c|}
\hline - & casaca & Tree & AUTO & Q 4825, 6438 \\
\hline- & - & Herb & EPIZO & Q4792 \\
\hline- & $\begin{array}{l}\text { são-joão-da- } \\
\text { caatinga }\end{array}$ & Hemiparasite & $\mathrm{ZOOC}$ & Q 6417; R 43 \\
\hline- & enxerto & Hemiparasite & $\mathrm{ZOOC}$ & Q4868 \\
\hline 7 & murici & Shrub & ZOOC & Q4798, 6445; R 32 \\
\hline- & malva & Sub-shrub & ANEM & Q4885 \\
\hline- & malva & Sub-shrub & ANEM & Q4889 \\
\hline- & puçá & Tree & ZOOC & Q 4890, 6437; R 54 \\
\hline- & - & Sub-shrub & EPIZO & Q4810 \\
\hline- & papaconha & Herb & EPIZO & Q 4809; R 35 \\
\hline 1 & araçá-de-boi & Tree & ZOOC & Q 4799; R 6 \\
\hline- & $\begin{array}{l}\text { resineiro, araçá- } \\
\text { de-veado }\end{array}$ & Tree & ZOOC & Q 4820; R 21, 38 \\
\hline- & ameixa & Shrub & ZOOC & Q 4817; R 19 \\
\hline- & - & Herb & ANEM & Q 4807; R 27 \\
\hline- & $\begin{array}{l}\text { vara-de-curral, pau- } \\
\text { de-curral }\end{array}$ & Tree & ANEM & Q4830,4863,4866;R52 \\
\hline- & juá & Tree & $\mathrm{ZOOC}$ & Q4763,4860 \\
\hline- & marmelada & Shrub & ZOOC & $\mathrm{R} 17$ \\
\hline- & canelinha & Sub-shrub & AUTO & Q 4786; R 31 \\
\hline- & chumbinho & Liana & ANEM & Q 4802; R 10 \\
\hline- & - & Liana & ANEM & Q6443 \\
\hline- & quixaba & Tree & ZOOC & Q 4837, 6427 \\
\hline- & - & Herb & AUTO & Q 4805, 4815 \\
\hline 3 & pra-tudo & Tree & ZOOC & Q 4864, 6433; R 1 \\
\hline- & vassourinha-preta & Sub-shrub & $?$ & R3 \\
\hline- & - & Sub-shrub & AUTO & Q4884 \\
\hline 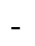 & - & Shrub & AUTO & Q4883 \\
\hline
\end{tabular}




\begin{tabular}{|c|c|c|c|c|c|}
\hline Family/Species & Code & Vernacular names & Habit & $\begin{array}{l}\text { Dispersal } \\
\text { syndrome }\end{array}$ & Voucher \\
\hline \multicolumn{6}{|l|}{ TURNERACEAE } \\
\hline $\begin{array}{l}\text { Piriqueta duarteana (Cambess.) } \\
\text { Urb. var. duarteana }\end{array}$ & 12 & malva & Sub-shrub & AUTO & Q 4791; R 42 \\
\hline Turnera diffusa Willd. ex Schult. & - & - & Sub-shrub & AUTO & Q4806,4822 \\
\hline Turnera opifera Mart. & - & - & Sub-shrub & AUTO & Q4876 \\
\hline \multicolumn{6}{|l|}{ VERBENACEAE } \\
\hline Lantana caatingensis Moldenke & - & - & Shrub & $\mathrm{ZOOC}$ & Q4875 \\
\hline \multicolumn{6}{|l|}{ VISCACEAE } \\
\hline Phoradendron linearifolium Eichl. & - & enxerto & Hemiparasite & $\mathrm{ZOOC}$ & Q4880 \\
\hline
\end{tabular}

area and all belong to the family Cactaceae. Epiphytes were absent, climbing species (vines + lianas) represent $10.6 \%$ of the sampled species and there was only $3.5 \%$ of hemiparasitic species.

The point-quarter method was able to sample 22 species in the area. The number of sampled individuals of the two most abundant species (Eugenia sp. and Copaifera coriacea) represented almost $50 \%$ of total individuals of all species $(n=832)$, whereas 14 other species represented together only about $10 \%$. Total density of woody species in both grids was very similar $\left(1089 \pm 55\right.$ and $1074 \pm 51$ individuals.ha $\left.{ }^{-1}\right)$. The densities per species calculated based on the summation of both grids are shown in table 2. Given their similarity, both grids were also summed in the other analyses.

The profile of woody plant community is low: twothirds of all individuals higher than 1.5 meters is 2 meters high or shorter, and only $5 \%$ is taller than 4.5 meters (figure 1). Only three species (Bombacopsis retusa, Mouriri pusa, and Pterocarpus monophyllus) have height mode equal or higher than 5.0 meters but their total frequency represent less than $1 \%$ of total community.

Between $98 \%$ and $100 \%$ of the individuals of the six species analyzed in 1989 had leaves. Flowers were present in individuals of Jatropha mutabilis (13.5\% of all individuals), Copaifera coriacea (5\%) and, to a lesser degree, in Eugenia sp. (0.9\%) and Byrsonima gardnerana $(0.6 \%)$. Fruits were present for B. gardnerana $(40.1 \%)$, J. mutabilis $(24 \%)$ and Eugenia sp. (16.6\%) and, to a lesser extent, for C. coriacea $(1.4 \%)$. A non-quantitative evaluation of fruiting for the same species in 1988 detected that fruits were common only for Simaba ferruginea and Bombacopsis retusa and that fruits of Eugenia sp. were found mainly in the soil.
Results from the broader phenologic analysis carried on from 1996 to 1997 are presented in figure 2 . The graphs show that the budding and shedding of leaves, development and anthesis of flowers, and production and dispersion of fruits were not synchronized among the most abundant species. The graphs based on total values of the community show that about $50 \%$ of the individuals were producing leaves all over the year, but this value rose to $74 \%$ by December. Shedding was the greatest in September (72\%) and reduced progressively to about $25 \%$ in March. Occurrence of development and anthesis of flowers were evenly distributed by the year reaching the greatest values $(16 \%$ and $14 \%$ respectively) in March/1997. Eugenia sp., Simaba ferruginea and Byrsonima gardnerana blossom and are in bloom during the dry season and in the beginning of the rainy season, while Copaifera coriacea and Maytenus rigida bloom in the climax of rainy season. Fruit development was the greatest $(36 \%)$ during December, when dispersion was the lowest (6\%).

The spectrum of dispersal syndromes is presented in figure 3. For the entire plant community, there is a predominance of autochorous species $(43.37 \%$ ) followed by zoochorous ( $31.11 \%)$, anemochorous $(16.87 \%)$ and epizoochorous species (8.43\%). However, these proportions are not homogeneously distributed among the different life forms. All of the hemiparasites and succulent species are zoochorous and all but one species of lianas are anemochorous. Epizoochory was almost restricted to herbs and sub-shrubs (6 species) except for one vine. Fleshy fruits or seed arils are absent among herbs and sub-shrubs except for the terrestrial bromeliad Bromelia antiacantha. On the other hand, among the phanerophytes (trees + shrubs), zoochory is the most important dispersal syndrome, accounting for $50 \%$ of the trees and $28.6 \%$ of the shrubs. 
Table 2. Frequency of occurrence, accumulated percentage and density of the most abundant woody plant species in the dunes of Ibiraba, Bahia, Brazil, as estimated by the point-quarter method based on individuals taller than 1.5 meters sampled in two grids.

\begin{tabular}{|c|c|c|c|c|}
\hline Rank & Species & Frequency & $\begin{array}{c}\text { Accumulated } \\
\text { percentage }(\%)\end{array}$ & $\begin{array}{l}\text { Density } \\
\text { (ind.ha }^{-1} \text { ) }\end{array}$ \\
\hline 1 & Eugenia sp. & 284 & 34.1 & 370 \\
\hline 2 & Copaifera coriacea & 123 & 48.9 & 160 \\
\hline 3 & Simaba ferruginea & 80 & 58.5 & 104 \\
\hline 4 & Maytenus rigida & 77 & 67.8 & 100 \\
\hline 5 & Croton sonderianus & 68 & 76.0 & 89 \\
\hline 6 & Chamaecrista belemii & 48 & 81.7 & 62 \\
\hline 7 & Byrsonima gardnerana & 44 & 87.0 & 57 \\
\hline 8 & Harpochilus neesianus & 29 & 90.5 & 38 \\
\hline 9 & Bocoa mollis & 22 & 93.1 & 29 \\
\hline 10 & Jatropha mutabilis & 19 & 95.4 & 25 \\
\hline 11 & Pilosocereus tuberculatus & 12 & 96.9 & 16 \\
\hline 12 & Bombacopsis retusa & 5 & 97.5 & 7 \\
\hline 13 & Ruprechtia ramiflora & 5 & 98.1 & 7 \\
\hline 14 & Peltogyne pauciflora & 4 & 98.6 & 5 \\
\hline 15 & Ouratea glaucescens & 3 & 98.9 & 4 \\
\hline 16 & Cratylia mollis & 2 & 99.2 & 3 \\
\hline 17 & Mouriri pusa & 2 & 99.4 & 3 \\
\hline 18 & Ximenia americana & 1 & 99.5 & 1 \\
\hline 19 & Pterocarpus simplicifolius & 1 & 99.6 & 1 \\
\hline 20 & Commiphora leptophloeos & 1 & 99.9 & 1 \\
\hline 21 & Senna gardneri & 1 & 99.9 & 1 \\
\hline 22 & Pilosocereus gounellei & 1 & 100.0 & 1 \\
\hline Total & & 832 & 100.0 & 1,083 \\
\hline
\end{tabular}

When superimposing the dispersal syndromes on the phytosociological data, the highest importance of zoochory for the studied community is observed. Fourteen out of the 22 surveyed species are zoochorous accounting for $78.7 \%$ of the total frequency and $78.6 \%$ of the total density. Except for two succulent and one hemiparasite species, all of these species are trees and shrubs. The second class is represented by the autochorous species which contributes for $20.7 \%$ of the total frequency and $20.8 \%$ of the total density. Only one surveyed species is anemochorous, contributing for ca. $0.6 \%$ of both the total frequency and density.

After a preliminary analysis, the values of the contribution of trees and shrubs were summed and the variables TRE and SHR were replaced in PCA analysis by the variable $T \& S$. The linearity of the relationship for every pair of variables is one of the conditions for performing the factor analysis. A visual inspection of the scatter graph matrix for the chosen variables shows that linearity is not evident in most of the cases. Based, however, in the suggestion that a straight line is always a good approximation for a monotonic function, most of the variance of the original data must be explained by the loadings resulting from the factor analysis (Harman 1976) and it is still an useful instrument both for systematizing a great amount of data and to generate hypotheses (Gauch 1982). Three principal components representing $68.5 \%$ of the total variance of primary data were extracted in the PCA analysis. The first component (eigenvalue $=2.25$ ) explains $25.1 \%$ of the total variance of the data. It is explained by the positive association among the variables SHA, T\&S, LIT, HEI, and negative association with DIS and represents a gradient of increasing density of woody plants. The second component (eigenvalue $=2.24$ ) explains as much of the total variance as the first one (24.9\%). It is explained by positive association between VAL and HER and represents a topographic and plant gradient of increasing amount of Bromelia antiacantha and Tacinga inamoena in the direction of valleys. The third component (eigenvalue $=1.67$ ) explains $18.6 \%$ of the variance and represents a topographic gradient, from 

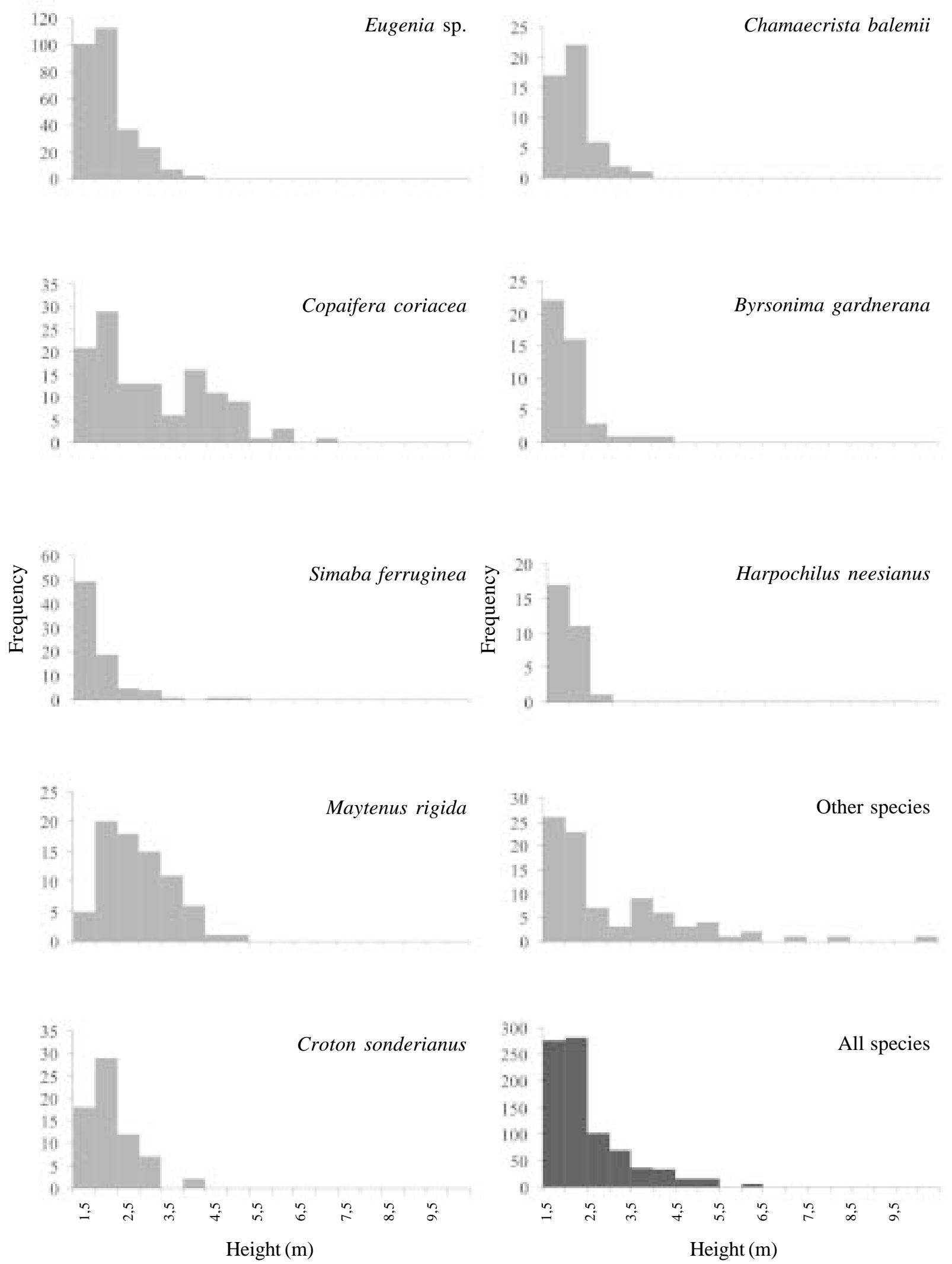

Figure 1. Height distribution of the main woody plants taller than 1.5 meters in the dunes of Ibiraba, Bahia. 
Leaves
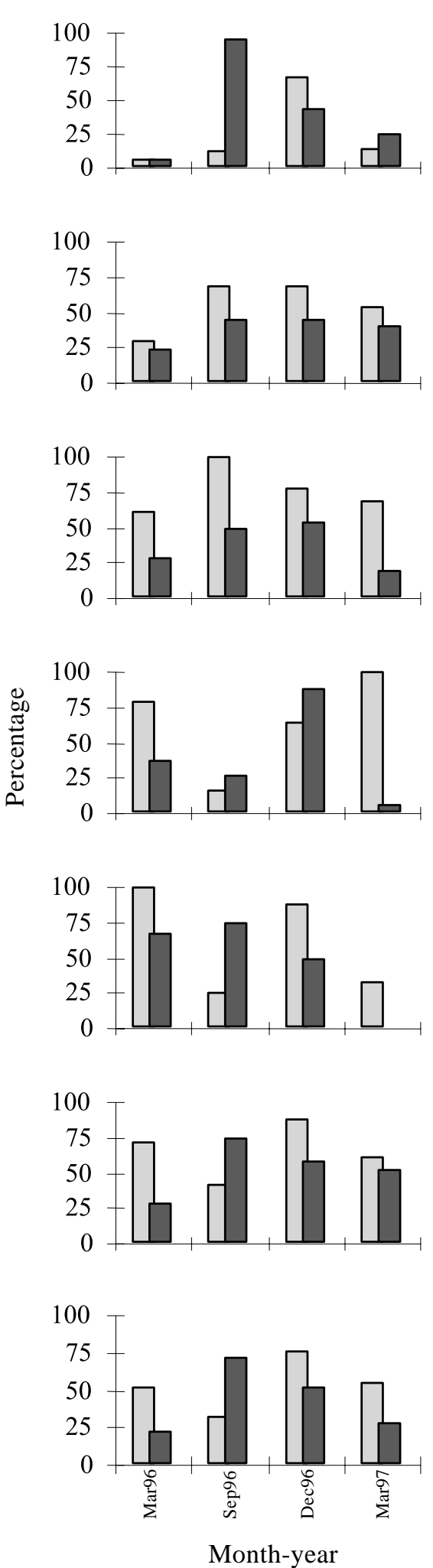

Flowers

Eugenia sp. (34.1\%)

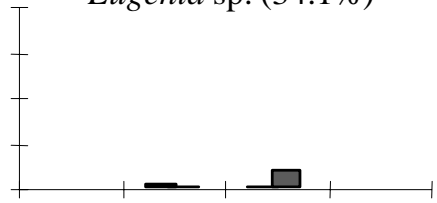

Copaifera coriacea $(14.8 \%)$

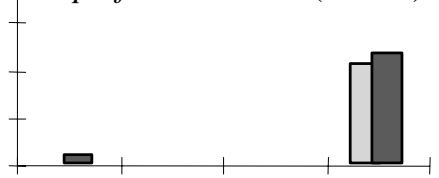

Simaba ferruginea $(9.6 \%)$
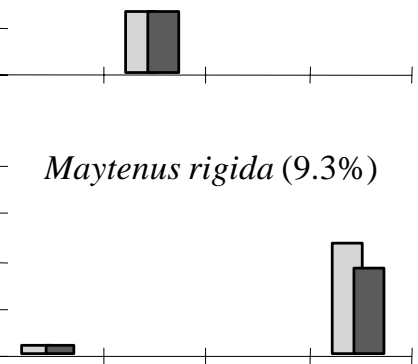

Byrsonima gardnerana (5.3\%)

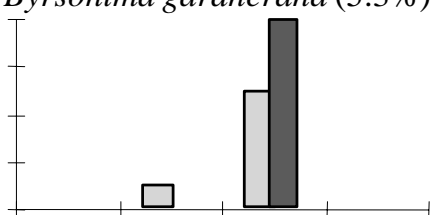

Other species $(26.9 \%)$

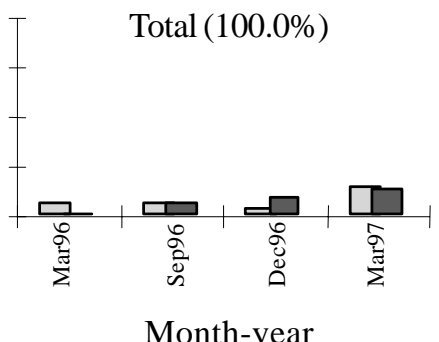

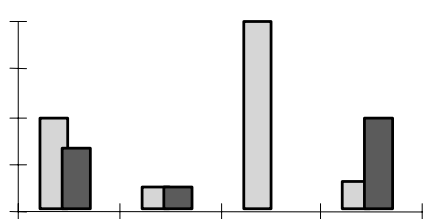

Fruits
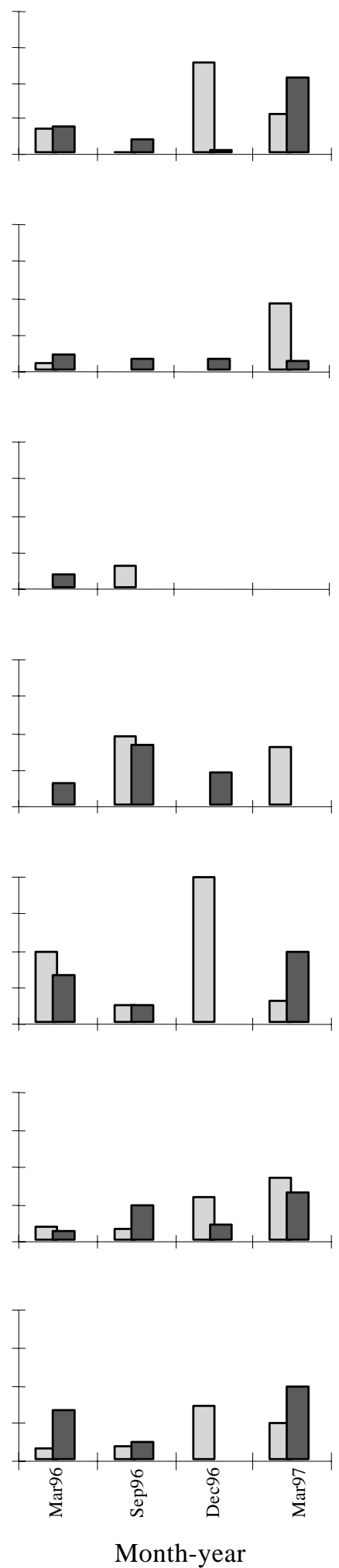

Figure 2. Phenologic state of the main woody plant species in the dunes of Ibiraba, Bahia, as quantified in four periods between 1996 and 1997. Clear bars represent budding (leaves), development (flowers), and production (fruits); dark bars represent shedding (leaves), anthesis (flowers), and dispersion (fruits). Values in parentheses refer to the relative abundance of the species. 


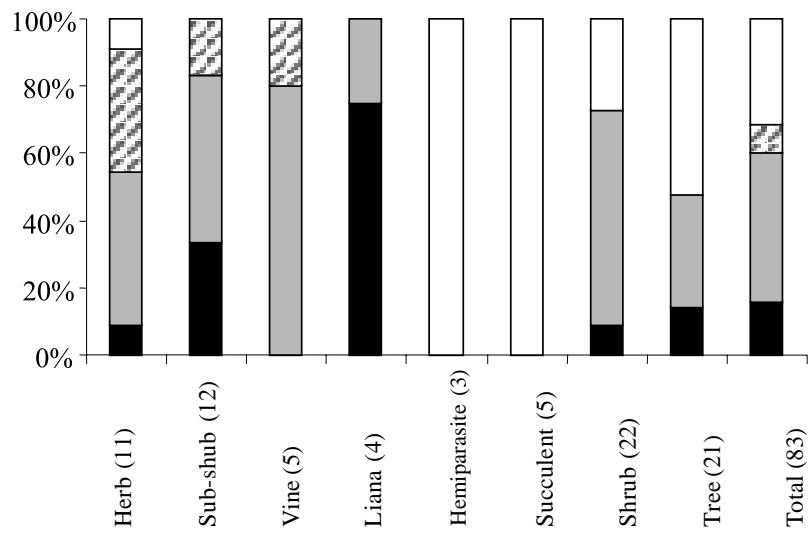

Figure 3. Spectrum of dispersal syndromes related to the life forms of the plant species in the dunes of Ibiraba, Bahia. Black bars = anemochory; gray bars = autochory + barochory; stripped bars = epizoochory; white bars = zoochory (fleshy fruits or with fleshy seed arils). Numbers in parentheses refer to number of species presenting the given life form.

summits to slopes. Figure 4 shows two-dimensional plots of component loadings. Figure 5 shows three profiles of the local plant community.

\section{Discussion}

Biogeography - The richness of plant species is low as compared to other Caatinga sites. We found 43 woody species and floristic surveys carried on other areas of Caatinga using similar methods as the presented here found 44 to 59 woody species (Lyra 1982, Araújo et al. 1995). The reduced number of species in the herbaceous/ sub-shrub cover in the dunes is also found in other habitats in the bioma Caatinga: $31.7 \%$ of the species against $50.5 \%$ of trees and shrubs in Buíque, state of Pernambuco (Gomes 1999); $21.6 \%$ against $61.9 \%$ in Caruaru, state of Pernambuco (Alcoforado-Filho 2003); and $20.1 \%$ against $58.6 \%$ in Novo Oriente, state of Ceará (Araújo et al. 1998). Many of the species present in the dunes are typical from sandy soil areas in the Caatinga biome. They are present mainly in two wide areas: (a) the paleodunes of the São Francisco River between Ibiraba (ca. 10 $0^{\circ} 8^{\prime} \mathrm{S}$ ) and Casa Nova (ca. $09^{\circ} 20^{\prime} \mathrm{S}$ ) in the Sate of Bahia extending North as far as the Gurguéia Valley, in the Southeast of the State of Piauí (ca. 09 $00^{\circ}$ S) and (b) the sedimentary deposits of Tucano-São Francisco, in the Moxotó Valley, State of Pernambuco (ca. 08³0' S), to the Raso da Catarina, State of Bahia (ca. 0950' S). Examples of species ranging along the cited areas are Bocoa mollis, Calliandra macrocalyx, Copaifera coriacea, Cratylia mollis, Hymenaea eryogyne, Senna gardneri (Leguminosae), Harpochilus neesianus (Acanthaceae), Tacinga inamoena (Cactaceae), Byrsonima gardnerana (Malpighiaceae), Godmania dardanoi (Bignoniaceae) and Jatropha mutabilis (Euphorbiaceae). Many of these species occur disjunctly in remote dry sandy areas in the Ibiapaba (ca. 0400' S) and Araripe (ca. 07³0' S) regions (Araújo et al. 1998). Other species from the dunes have a very restricted geographic distribution and are probably endemic from the study area, as the Leguminosae Dioclea marginata, Mimosa xiquexiquensis (Barneby 1991), Pterocarpus
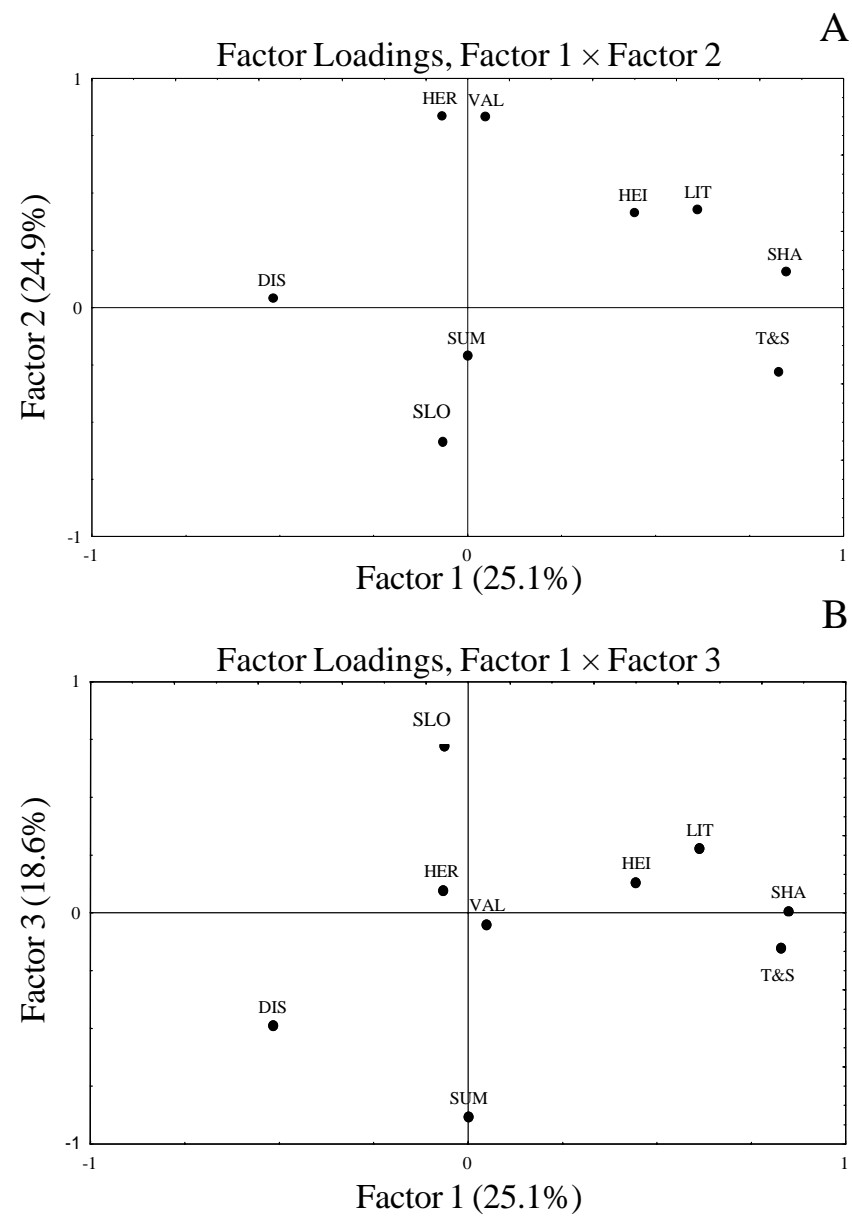

Figure 4. Results of PCA analysis for nine plant and microhabitat variables from the dunes of Ibiraba, Bahia. (A) Plot of nine microhabitat variables on first and second principal components. (B) Plot of nine microhabitat variables on first and third principal components. Values in parentheses refer to the percentage of the data variation explained by the factor. DIS $=$ mean distance to the nearest woody plant $\mathrm{HEI}=$ mean height of woody plants; HER = herbaceous cover; LIT = amount of litter; SHA = amount of shade; $\mathrm{SLO}=$ dune slope; $\mathrm{SUM}=$ dune summit; $\mathrm{T} \& \mathrm{~S}=$ tree and shrub cover; $\mathrm{VAL}=$ dune valley. See text for details. 

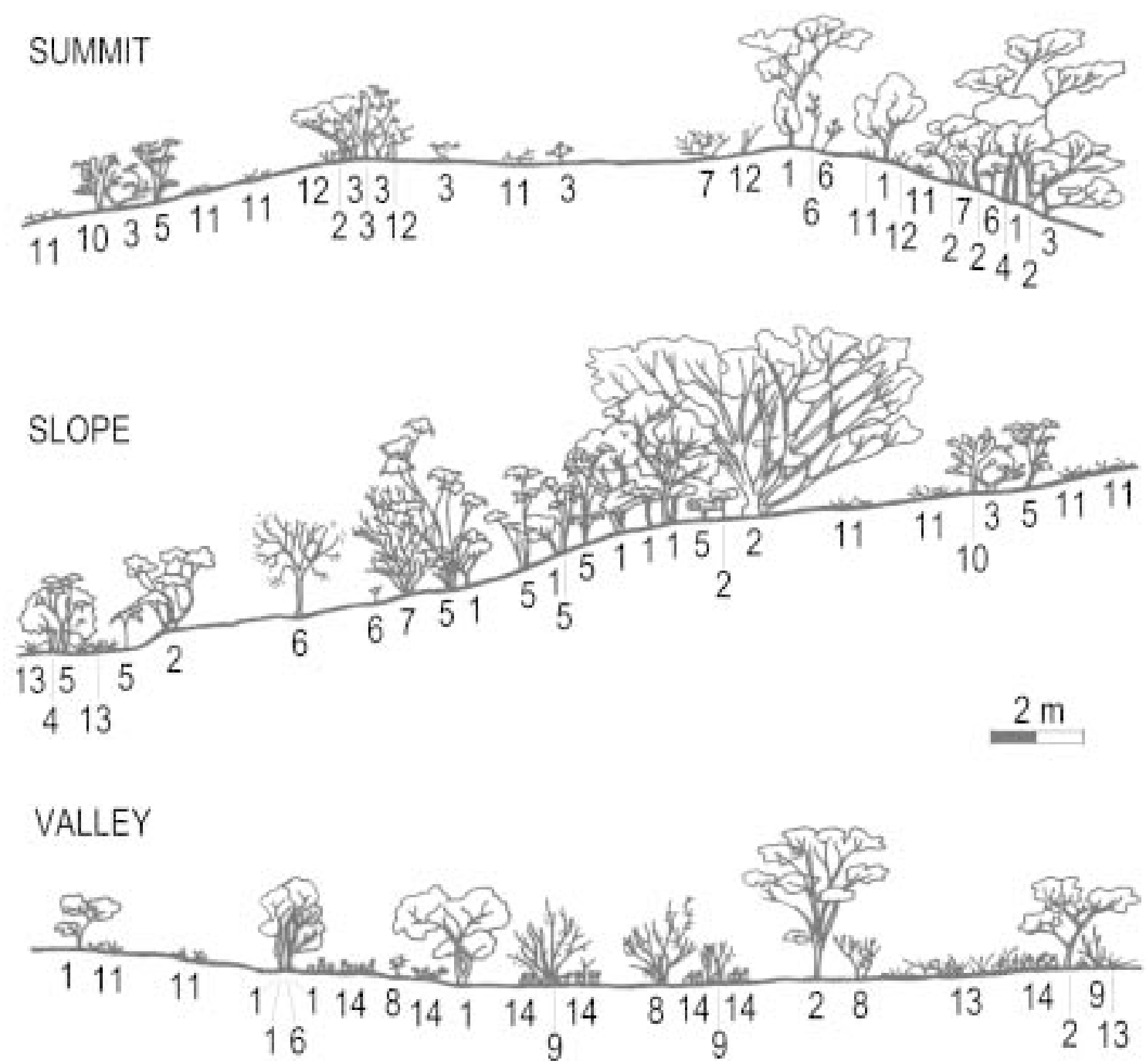

Figure 5. Three profiles of plant community on the dunes in Ibiraba, Bahia. The plants inside a strip 2 meter wide (perpendicular to dunes crests) are represented in different microgeographic positions (summit, slope, and valley). Numbers represent the codes of the species in the table 1.

monophyllus (Klitgaard et al. 2000), the Myrtaceae Eugenia sp., and the Molluginaceae Glischrothamnus ulei (Harley 1996).

Geographical distribution and paleoclimatic evidences (Prado \& Gibbs 1993, Pennington et al. 2000, Prado 2000) suggest that the Neotropical seasonally dry forests must represent a phytogeographic unity, including the Caatinga in Norteastern Brazil. However, from the 57 Caatinga woody species used by Pennington and colleagues (Pennington et al. 2000) for the delimitation of the seasonally dry tropical forests, only Commiphora leptophloeos (Burseraceae) is found in the dunes, although other species cited by the authors occur in the Caatinga and gallery forests near the dunes, as Couepia uiti (Mart. \& Zucc.) Benth. (Chrysobalanaceae), Albizia inundata (Mart.) Barneby
\& J.W. Grimes, Geoffroea spinosa Jacq., and Peltophorum dubium (Spreng.) Taub. (Leguminosae). Moreover, species included in that phytogeographic unity are rarely found in other sandy areas in the Caatinga biome (see floristic checklists in Araújo et al. 1998, Figueirêdo et al. 2000). This suggests that the plants inhabiting the dunes in the middle São Francisco River (or even those inhabiting other sandy areas inside the limits of the biome Caatinga) may represent one phytogeographic unity different from the seasonally tropical dry forests (species inhabiting nonsandy areas in Caatinga). This hypothesis of distinct historical processes acting in the different phytogeographic unities seems to be corroborated by the analysis of the geographic distribution of some animals. 
Regarding the fauna present in the dunes, all the most abundant terrestrial vertebrate species present there are endemic. In one ecological study focusing the lizard community in the area, 7 out of 11 lizard species captured in pitfall traps were endemic, corresponding to $98 \%$ of 879 collected individuals (Rocha 1998). Another study on terrestrial small mammals was based on 8,860 trapnights and resulted in 264 captured individuals, 263 representing a single endemic species of echimyid rodent (Rocha 1991, 1995, Rocha, unpublished data). Also new species of arthropods of the middle São Francisco have been described in the area (e.g., Xavier \& Rocha 2001), although species of this group should not be regarded as endemic before further analysis of data from other Caatinga areas, which are still scanty. It seems that the evolution of the endemic species of both plants and animals in the dunes could be derived from the same biogeographical process. Regarding the sandy areas in Caatinga, disjunct geographical distribution is known also for populations of the sand-dweller lizards Tropidurus cocorobensis (Rodrigues 2003) and for species of the fossorial and saxicolous genus Calyptommatus (Rodrigues 2001). Rodrigues has suggested that the distribution of the first one can be understood only admitting that the sandy areas were much wider in past (Rodrigues 2003). This scenario coincides with that proposed here for the plants inhabiting sandy areas in the Caatinga, since present isolated sandy areas may have been wider and closer to each other in the past.

Phenology - One of the most striking features of the Caatinga is the deciduousness of the leaves in the dry season. The proportion of the species that keep their leaves in the dry season ranges from 26\% (Machado et al. 1997) to almost zero, in areas where only Ziziphus joazeiro (Rhamnaceae) could be taken as evergreen (Oliveira et al. 1988). The studied site at Ibiraba is striking different from other caatinga areas since most species keep their leaves along the dry season and there is a continuous turnover of leaves during the year. In this respect, it is more similar to other sandy woodlands inside the Caatinga biome, as the carrasco vegetation of the Ibiapaba region (Araújo et al. 1998). The lower deciduousness in the dunes might reflect both different species composition and special adaptation of the plant species to this particular habitat. A definitive answer, however, should follow ecophysiological studies.

There is an almost complete absence of data about flowering and fruiting phenology of the plants of the caatinga. One of the most detailed study was presented by Machado et al. (1997) for a typical caatinga site in the state of Pernambuco where most of the woody species flower at the beginning of the rainy season. This flowering pattern was observed in other seasonally dry forests and seems to be more common at the drier sites (Bullock 1995) where most of the woody species flower nearly simultaneously with leaf expansion (Bullock \& Solís 1990, Guevara de Lampe et al. 1992). In the studied site, some species flower during the rainy season and others during the dry season, but at the community level it is not possible to correlate flowering activity with the rain distribution along the year, differently from other dry forests. Castro (1994) showed that there is a continuous action of pollinators (mainly eusocial bees) in some caatinga habitats along the year, and Viana (1999) showed that, in the dunes, bees are locally more abundant in rainy season but they do visit flowers also in the dry season. Therefore, the flowering pattern found could reflect this availability of pollinators. However, an unequivocal explanation to this pattern should rest on physiological analyses of the species based on a phylogenetic context.

Fruiting production starts at the beginning of the rainy season and dispersion occurs until the end of the dry season. Bullock (1995) concluded that, in tropical dry forests, fleshy fruits "are notoriously concentrated in wet season and scarse in the dry season" while anemochores and autochores are "absent or inconspicuous in the wet season and abundant in the dry season". It is interesting to note that in the studied site, fleshy fruits (including species with fleshy arils) are dispersed along the year, mainly from the end of the wet season to the end of the next dry season.

Dispersion syndromes showed some unexpected figures when compared with other neotropical dry forests. Medina (1995) observed that these forests may be characterized by a higher proportion of wind dispersed species. In the studied site, typical anemochorous species accounted only for $16.5 \%$ of the species, mostly lianas and sub-shrubs. Among the phanerophytes (tree + shrubs), 11 tree and six shrub species are typically zoochorous $(39.5 \%)$ and only six species of these two life forms (13.9\%) are anemochorous. The predominance of the zoochory in the Ibiraba site is highlighted when the dispersal syndromes are analyzed in combination with the phytosociological data showing that zoochorous plants account for ca. $78.7 \%$ of the total plant density and frequency. These data show a higher proportion of zoochorous species and a lower proportion of anemochorous species among the woody plants. In contrast with the pattern observed at the Ibiraba site, a 
typical dry forest site is reported to show higher proportions of anemochorous plants (Bullock 1995). For example, at Charallave (Venezuela), Wikander (1984) found $30.5 \%$ of the phanerophytes as typical anemochorous species.

Thus, both the phenological data of leaf deciduousness and flowering, as well as the dispersal syndromes data, reinforce the suggestions advanced by biogeographical data that the sandy dune vegetation of the São Francisco river may represent a phytogeographical unity different from the typical Caatinga or other neotropical dry forests. Similar studies in other sites could show if this inference could be generalized for the dry vegetation on sandy soil inside the Caatinga Dominium.

Habitat structure - The physiognomy of the plant community on the sand dunes in Ibiraba is quite different from the surrounding Caatinga formations. It lacks almost completely the herbaceous cover composed of annual or perennial species in the families Amaryllidaceae, Leguminosae, Graminae, Portulacaceae and Zygophyllaceae. Even during the rainy months, only $15 \%$ of the soil is covered by low, non-woody plants, most of which are mixed patches of Bromelia antiacantha and Tacinga inamoena (species until recently known in the literature as Opuntia inamoena). As the woody plants are sparse, $45.8 \%$ of the ground represents totally exposed sand.

Medina (1995) showed that the structure of the community changes along the rainfall gradient and noted that the most striking features changing in life forms along this gradient are related to tree height and degree of deciduousness. The long dry season could account for the low height of the trees observed in the studied site, agreeing with Medina (1995). On the other hand, many of the life forms expected for dry areas (Medina 1995) are absent or very rare at the Ibiraba site as, for example, sclerophyllous woody plants, non-succulent herbs, epiphytes, and lianas (woody vines). The life forms distribution observed in Ibiraba is more similar to those found in other sandy areas within the Caatinga biome, as in the Ibiabapa (Araújo et al. 1998) and the Buíque (Figueirêdo et al. 2000) regions. One striking feature of the physiognomy of the Ibiraba vegetation is the patchy distribution of the woody plants. It seems to be different from the physiognomy of any other vegetation described in the Caatinga biome and may result from the combined effect of the sandy substratum and sloped landscape.

The habitat of the dunes is also very simple and homogeneous in structure. The trees and shrubs have a low profile and the topography is very repetitive, seemingly influencing the distribution of the patches of Bromelia and Tacinga (common in valleys). The woody plants do not seem to be influenced as a group by topography. However, as the mean distance to the closest trees and shrubs and their mean heights lie in different poles in the first axis of PCA, the taller plants tend also to form patches, which are very shaded and full of litter. As result for the small cursorial fauna, there are two main categories of protected patches: mediumsized predators protected areas (clusters of spiny plants at the level of the surface) and small-size predators and sun protected areas (clusters of litter in the shadow), and one category of exposed patches (exposed sand). Different groups of animals seem to explore differentially these microhabitat resources (Rocha 1991, 1998, Xavier \& Rocha 2001, Xavier, unpublished data).

On the other hand, the dunes seem to offer to the local fauna a much more constant supply of resources than the Caatinga in the neighborhoods. Eugenia sp. is the most abundant woody species, representing $1 / 3$ of all trees and shrubs taller than $1.5 \mathrm{~m}$. Its seeds are the main source of food and water for the endemic rodents (Rocha 1991, Rocha, unpublished data). At least 50\% of the woody plants retain the leaves even in the driest months and there are flowers of different species in anthesis all over the year. Fruits, on the other hand, are very few in the beginning of the rainy season. The ways these resources seem to modulate the abundance and diversity of the local fauna of vertebrates and arthropods has been explored recently (Rocha 1991, 1998, Neves \& Viana 2002).

In spite of the apparent homogeneity of the habitat, the local diversity of lizards is high (17 syntopic species) compared to other open habitats in Brazil. In the Caatinga of Exu, Pernambuco, where habitat is highly heterogeneous due to the presence of granitic outcroppings, Vitt (1995) has found 18 species, a number considered by the author higher than most Caatinga habitats. Figures recorded for other open habitats are: 9 species in the Cerrados in Alto do Araguaia, Mato Grosso (Vitt 1991); 8 species in a "lavrado" area in Roraima (Vitt \& Carvalho 1995); 5 species in a Cerrado area in Rondônia (Vitt \& Caldwell 1993); 5 species in a Restinga (low coastal forest on sandy soil) area in Rio de Janeiro (Araujo 1991). In contrast, even much drier areas of Caatinga support a much more diversified small mammal fauna than the dunes (e.g., six species in the Caatinga of Curaçá, BA - Rodrigues et al., unpublished data).

The great amount of endemic taxa living on the dunes of Ibiraba (see also Rodrigues 1996) highlights 
the relevance of the area for both conservation purposes and academic studies.

Acknowledgements - Thanks are due to specialists that checked the identifications of plant specimens: A.C. Araújo (Cyperaceae), M.M. Arbo (Turneraceae), E. Cabral (Rubiaceae), I. Cordeiro (Euphorbiaceae), C.L. Cristóbal (Sterculiaceae), G.L. Esteves (Bombacaceae), M.S. Ferruci (Sapindaceae), D.J.N. Hind (Compositae), C. Kameyama (Acanthaceae), M.L. Kawasaki (Myrtaceae), A. Krapovickas (Malvaceae), R. Mello-Silva (Annonaceae), E. Melo (Polygonaceae), E.B. Miranda-Silva (Polygalaceae), R.P. Oliveira (Graminae), T.D. Pennington (Sapotaceae), M.M. Silva (Bignoniaceae), R. Simão-Bianchini (Convolvulaceae), V.C. Souza (Scrophulariaceae), N. Taroda-Ranga (Boraginaceae), D.C. Zappi \& N. Taylor (Cactaceae). We are deeply indebted to Dr. Miguel Trefaut Rodrigues, who has introduced us to the area and to Alexander Silveira Gomes, Eduardo Xavier de Oliveira Júnior, Evanira Maria Ribeiro, José Wellington Alves dos Santos and Larissa N. Sátiro, who have helped us in the field work. The work was supported by grants from the Conselho Nacional de Desenvolvimento Científico e Tecnológico (CNPq).

\section{References}

AB'SABER, A.N. 1974. O domínio morfoclimático semi-árido das caatingas brasileiras. Geomorfologia 43:1-39.

ALCOFORADO FILHO, F.G., SAMPAIO, E.V.S.B. \& RODAL, M.J.N. 2003. Florística e fitossociologia de um remanescente de vegetação espinhosa arbórea em Caruaru, Pernambuco. Acta Botanica Brasilica 17:287-303

ANDRADE-LIMA, D. 1981. The caatingas dominium. Revista Brasileira de Botânica 4:149-153.

ARAUJO, A.F.B. 1991. Structure of a white sand-dune lizard community of coastal Brazil. Revista Brasileira de Biologia 51:857-865.

ARAÚJO, E.L., SAMPAIO, E.V.S.B. \& RODAL, M.J.N. 1995. Composição florística e fitossociologia de três áreas de caatinga. Revista Brasileira de Biologia 55: 595-607.

ARAÚJO, F.S., SAMPAIO, E.V.S.B., FIGUEIREDO, M.A., RODAL, M.J.N. \& FERNANDES, A.G. 1998. Composição florística da vegetação de carrasco, Novo Oriente - CE. Revista Brasileira de Botânica 21:15-26.

BAHIA-SEPLANTEC. 1978. Atlas do estado da Bahia. Seplab, Salvador.

BARNEBY, R. 1991. Sensitivae Censitae, a description of the genus Mimosa L. (Mimosaceae) in the New World. Memoirs of the New York Botanical Garden 65:1-835.

BARRETO, A.M.F. 1996. Interpretação paleoambiental do sistema de dunas fixadas do médio rio São Francisco, Bahia. Tese de doutorado, Universidade de São Paulo, São Paulo.
BARROS, R.C.H., OLIVEIRA, E.S., ROCHA, P.L.B. \& BRANCO, L.L.G.S. 1998. Respiratory and metabolic responses of the spiny rats $P$. yonenagae and $P$. ihering $i$ to $\mathrm{CO}_{2}$. Respiration Physiology 111:223-231.

BULLOCK, S.H. 1995. Plant reproduction in neotropical dry forests. In Seasonally dry tropical forests (S.H. Bullock, H.A. Mooney \& E. Medina, eds). Cambridge University Press, New York, p.277-303.

BULLOCK, S.H. \& SOLÍS M., J.A. 1990. Phenology of canopy trees of a tropical deciduous forest in Mexico. Biotropica 22:22-35.

CASTRO, M.S. 1994. Composição, fenologia e visita às flores pelas espécies de Apidae em um ecossistema de Caatinga (Nova Casa Nova - Bahia 9²6'S / 41 ${ }^{\circ} 50^{\prime} \mathrm{W}$ ). Dissertação de mestrado, Universidade de São Paulo, São Paulo.

FERRI, M.G. 1955. Contribuição ao conhecimento da ecologia do cerrado e da caatinga. Estudo comparativo da economia d'água e de sua vegetação. Tese de doutorado, Universidade de São Paulo, São Paulo.

FIGUEIRÊDO, L.S., RODAL, M.J.N. \& MELO, A.L. 2000. Florística e fitossociologia de uma área de vegetação arbustiva caducifólia espinhosa no município de Buíque - Pernambuco. Naturalia 25:205-224.

GAUCH, H.G. 1982. Multivariate analysis in ecology. Cambridge University Press, Cambridge.

GIULIETTI, A.M., HARLEY, R.M., QUEIROZ, L.P., BARBOSA, M.R.V., BOCAGE NETA, A.L. \& FIGUEIREDO, M.A. 2002. Espécies endêmicas da Caatinga. In Vegetação e Flora da Caatinga (E.V.S.B. Sampaio, A.M. Giulietti, J. Virgínio \& C.F.L. Gamarra-Rojas, eds.), Associação Plantas do Nordeste, Recife, p.103-118.

GOMES, A.P.S. 1999. Florística e fitossociologia de uma vegetação arbustiva subcaducifólia no município de Buíque - Pernambuco. Dissertação de mestrado, Universidade Federal Rural de Pernambuco, Pernambuco.

GUEVARA-DE-LAMPE, M., BERGERON, Y., MCNEIL, R. \& LEDUC, A. 1992. Seasonal flowering and fruiting patterns in tropical semi-arid vegetation in northeastern Venezuela. Biotropica 24:64-76.

HARLEY, R.M. 1996. Examples of endemism and phytogeographical elements in the caatinga flora. In Anais da Reunião Especial da Sociedade Brasileira para o Progresso da Ciência. SBPC, Feira de Santana, p.219-227.

HARMAN, H.H. 1976. Modern factor analysis. Chicago University Press, Chicago.

HOLBROOK, N.M., WHITBECK, J.L. \& MOONEY, H.A. 1995. Drought responses of neotropical dry forest trees. In Seasonally dry tropical forests. (S.H. Bullock, H.A. Mooney \& E. Medina, eds.), Cambridge University Press, New York, p.243-272.

HOLMGREN, P.K., HOLMGREN, N.H. \& BARNETT, L.C. 1990. Index Herbariorum. Ed. 8. The New York Botanical Garden, New York. 
KLEIBAUN, D.G., KUPPER, L.L. \& MULLER, K.E. 1988. Applied regression analysis and other multivariate methods. PWS-KENT Publishing Company, Boston,

KLITGAARD, B.B., QUEIROZ, L.P. \& LEWIS, G.P. 2000. A new species of Pterocarpus (Leguminosae: Dalbergieae) from Bahia, Brazil. Kew Bulletin 55:732-735.

KREBS, C.J. 1999. Ecological methodology. Addison Wesley Logman, California.

LENCIONI NETO, F. 1994. Une nouvelle espèce de Chordeiles (Aves, Caprimulgidae) de Bahia (Brésil). Alauda 62:241-245.

LYRA, A.L.R.T. 1982. A condição de ‘brejo’ e o efeito do relevo na vegetação de duas áreas no município de Brejo da Madre de Deus-PE. Dissertação de mestrado, Universidade Federal Rural de Pernambuco, Recife.

MACHADO, I.C.S., BARROS, L.M. \& SAMPAIO, E.V.S.B. 1997. Phenology of the caatinga species at Serra Talhada, PE, Northeastern Brazil. Biotropica 29:57-68.

MARES, M.A., WILLIG, M.R. \& LACHER JUNIOR, T.E. 1985. The Brazilian Caatinga in South American zoogeography: tropical mammals in a dry region. Journal of Biogeography 12:57-69.

MAXWELL, R.H. 1969. The genus Dioclea in the New World. Doctoral thesis, University of Illinois, Carbondale.

MEDINA, E. 1995. Diversity of life forms of higher plants in neotropical dry forests. In Seasonally dry tropical forests (S.H. Bullock, H.A. Mooney \& E. Medina, eds.), Cambridge University Press, New York, p.221-242.

NEVES, E.L. \& VIANA, B.F. 2002. Abelhas eussociais (Hymenoptera, Apidae) visitantes florais em um ecossistema de dunas continentais no médio rio São Francisco, Bahia, Brasil. Revista Brasileira de Entomologia 46:573-580.

NIMER, E. 1979. Climatologia do Brasil. IBGE, Rio de Janeiro.

OLIVEIRA, J.G.B., QUSEADO, H.L.C., NUNES, E.P. \& VIANA, F.A. 1988. Observações preliminares de fenologia de plantas de caatinga na Estação Ecológica de Aiuaba, Ceará, Esam, Mossoró. Coleção Mossoroense, série B, n. 538.

OLIVEIRA, P.E., BARRETO, A.M.F. \& SUGUIO, K. 1999. Late Pleistocene/Holocene climatic and vegetational history of the Brazilian caatinga: the fossil dunes of the middle São Francisco River. Palaeogeography, Palaeoclimatology, Palaeoecology 152:319-337.

OLIVEIRA, J.A., GONÇALVES, P.R. \& BONVICINO, C.R. 2003. Mamíferos da caatinga. In Ecologia e conservação da caatinga (I.R. Leal, M. Tabarelli \& J.M.C. Silva, eds.). Editora Universitária da UFPE, Recife, p.275-302.

PENNINGTON, R.T., PRADO, D.E. \& PENDRY, C.A. 2000. Neotropical seasonally dry forests and Quaternary vegetation changes. Journal of Biogeography 27:261-273.

PIJL, L. VAN DER. 1972. Principles of dispersal in higher plants. McGraw-Hill, New York.
PRADO, D.E. 2000. Seasonally dry forests of tropical South America: from forgotten ecosystems to a new phytogeographic unit. Edinburgh Journal of Botany 57:437-461.

PRADO, D.E. \& GIBBS, P.E. 1993. Patterns of species distribution in the dry seasonal forests of South America. Annals of the Missouri Botanical Garden 80:902-927.

RIBEIRO, M.F.S., ROCHA, P.L.B., MENDES, L.A.F., PERRY, S.F. \& OLIVEIRA, E.S. 2004. Physiological effects of short-term water deprivation in the South American sigmodontine rice rat Oligoryzomys nigripes and water rat Nectomys squamipes within a phylogenetic context. Canadian Journal of Zoology 82:1326-1335.

RIZZINI, C.T. 1979. Tratado de fitogeografia do Brasil. Editora de Humanismo e Tecnologia - Editora da Universidade de São Paulo, São Paulo, v.2.

ROCHA, P.L.B. 1991. Ecologia e morfologia de uma nova espécie de Proechimys (Rodentia: Echimyidae) das dunas interiores do Rio São Francisco (BA). Dissertação de mestrado, Universidade de São Paulo, São Paulo.

ROCHA, P.L.B. 1995. Proechimys yonenagae, a new species of spiny rat (Rodentia: Echimyidae) from fossil sand dunes in Brazilian Caatinga. Mammalia 59:537-550.

ROCHA, P.L.B. 1998. Uso e partição de recursos pelas espécies de lagartos das dunas do rio São Francisco, Bahia (Squamata). Tese de doutorado, Universidade de São Paulo, São Paulo.

RODAL, M.J.N. \& SAMPAIO, E.V.S.B. 2002. A vegetação do bioma caatinga. In Vegetação e Flora da Caatinga (E.V.S.B. Sampaio, A.M. Giulietti, J. Virgínio \& C.F.L. Gamarra-Rojas, eds.), Associação Plantas do Nordeste, Recife, p.11-24.

RODRIGUES, M.T.U. 1996. Lizards, snakes and amphisbaenians of the palaeoquaternary sand dunes of the middle São Francisco River: Bahia: Brazil. Herpetologica 30:513-523.

RODRIGUES, M.T.U. 2001. A new species of lizard, genus Calyptommatus, from the caatinga of the sate of Piauí, northeastern Brazil (Squamata, Gymnophtalmidae). Papéis Avulsos de Zoologia 41:529-546.

RODRIGUES, M.T.U. 2003. Herpetofauna da Caatinga. In Ecologia e conservação da caatinga (I.R. Leal, M. Tabarelli \& J.M.C. Silva, eds.). Editora Universitária da UFPE, Recife, p.181-236.

SAMPAIO, E.V.S.B. 1995. Overview of the Brazilian Caatinga. In Seasonally dry tropical forests (S.H. Bullock, H.A. Mooney \& E. Medina, eds.). Cambridge University Press, New York, p.35-63.

STREILEIN, K.E. 1982a. Ecology of small mammals in the semiarid Brazilian caatinga. I. Climate and faunal composition. Annals of the Carnegie Museum 51:79-107.

STREILEIN, K.E. 1982b. Ecology of small mammals in the semiarid Brazilian caatinga. II. Water relations. Annals of the Carnegie Museum 51:109-126. 
STREILEIN, K.E. 1982c. Ecology of small mammals in the semiarid Brazilian caatinga. IV. Habitat selection. Annals of the Carnegie Museum 51:331-343.

VANZOLINI, P.E., RAMOS-COSTA, A.M.M \& VITT, L.J. 1980. Répteis das caatingas. Academia Brasileira de Ciências, Rio de Janeiro.

VIANA, B.F. 1999. A comunidade de abelhas (Hymenoptera: Apoidea) das dunas interiores do Rio São Francisco, Bahia, Brasil. Anais da Sociedade Entomológica do Brasil 28:635-645.

VITT, L.J. 1991. An introduction to the ecology of cerrado lizards. Journal of Herpetology 25:79-80.

VITT, L.J. 1995. The ecology of tropical lizards in the caatinga of Northeast Brazil. Occasional Papers of the Oklahoma Museum of Natural History 1:1-29.
VITT, L.J. \& CALDWELL, J.P. 1993. Ecological observations on cerrado lizards in Rondônia, Brazil. Journal of Herpetology 27:46-52.

VITT, L.J. \& CARVALHO, C.M. 1995. Niche partitioning in a tropical wet season: lizards in the lavrado area of northern Brazil. Copeia 195:305-329.

WIKANDER, T. 1984. Mecanismos de dispersión de diásporas de una selva decídua en Venezuela. Biotropica 16:276-283.

WILLIG, M.R. \& MARES, M.A. 1989. Mammals from the caatinga: an updated list and summary of recent research. Revista Brasileira de Biologia 49:361-367.

XAVIER, E. \& ROCHA, L.S. 2001. Autoecology and description of Muтmисіa mauryi (Solifugae, Mummucidae), a new solifuge from Brazilian semi-arid Caatinga. The Journal of Arachnology 29:127-134. 